\title{
THE RELATIONSHIP OF RESPONDENT CHARACTERISTICS, KNOWLEDGE, ATTITUDES, AND OWNERSHIP OF LATRINES TOWARDS ITS LOW USE OF LATRINES IN GUNUNG ANYAR VILLAGE, SURABAYA CITY
}

\author{
Anca Laika ${ }^{1}$, Retno Adriyani ${ }^{1}$ \\ ${ }^{1}$ Department of Enviromental Health, \\ Faculty of Public Health, Airlangga University, Surabaya, Indonesia \\ Correspondence address: Anca Laika \\ E-mail: laikaanca@gmail.com
}

\begin{abstract}
Gunung Anyar Tambak village had the lowest access to latrines. Some residents defecate in rivers or other places. The study was conducted to determine a relationship of factors and low use of latrines in Gunung Anyar Tambak village. It was observational research with a cross sectional design. Samples were selected from the population through simple random sampling. Guided interviews were conducted to 75 respondents in RW 01 Gunung Anyar Tambak village. The research variables were respondent characteristics (education level and income level), knowledge, attitudes, and latrine ownership. Data analysis was done using the Chi-square test with a degree of confidence at $95 \%$. The results showed a significant relationship between respondent characteristics including education level $(p=0.000)$, income level $(p=0.000)$, knowledge $(p=0.006)$, attitude $(p=0.003)$, and latrine ownership ( $\mathrm{p}=0.000)$ on low use of latrines. The variable with the strongest relationship was latrine ownership.
\end{abstract}

Keywords: education, income, knowledge, attitude, latrine ownership

\section{INTRODUCTION}

More attention has to be brought to Indonesia's diverse sanitation problems, especially towards open defecation. In 2015, the World Health Organization (WHO) stated that $13 \%$ of the world's population still practiced open defecation, and the Southeast Asia's population who practiced it amounted to $34 \%$. This number was $21 \%$ higher than that of the world's population. The Southeast Asian region is still characterized by many developing countries. In Indonesia, the number of people whom practice open defecation decreased from $40 \%$ in 1990 to $22 \%$ in 2016; however, it has not yet reached the targets of National Medium-Term Development Plan.

In 2015-2019 National MediumTerm Development Plan, the Indonesian Ministry of Health has set a target on stopping $100 \%$ of open defecation cases. In 2015, as many as 64 million Indonesians could not access proper sanitation, and 34 million still defecated in open areas. Therefore, an acceleration of Community- based Total Sanitation (STBM) by $400 \%$ is needed to achieve this target (Indonesian Ministry of Health, 2018).

Observing the national cumulative access to sanitation, only Yogyakarta province has made a progress by $100 \%$. Other provinces such as East Java have access to sanitation by $89.71 \%$, South Sulawesi by $94.30 \%$, Bali by $92.30 \%$, Bangka Belitung by $91.47 \%$, and Central Java by $90.38 \%$ (Indonesian Ministry of Health, 2018). In 2017, East Java, out of its 38 districts/cities, only achieved 5 opendefecation-free (ODF) districts/cities, which were Madiun city, Magetan, Pacitan, Ngawi, and Lamongan districts. Thirtythree districts/cities in East Java are not yet ODF; one of them is Surabaya city (Indonesian Ministry of Health, 2018).

Based on the progress of sanitation access in 2017, residents of Surabaya city had 794,055 permanent healthy lastrines, 377,796 semi-permanent healthy lastrines, 19,166 shared latrines (used by more than 1 family), and 16,082 defecation cases. Fiftyfive out of 154 villages in Surabaya city were ODF; in other words, ninety-nine 
villages, e.g., Gunung Anyar Tambak village had not recieved the ODF status (Indonesian Ministry of Health, 2018).

In the East Surabaya areas, Gunung Anyar district had $97.48 \%$ access to latrines, the lowest among other districts i.e., Rungkut (99.30\%), Mulyorejo (99.19\%), Sukolilo (99.03\%), Tenggilis Mejoyo (98.90\%), Tambaksari (98.63\%), and Gubeng (98.33\%). Specifically, Gunung Anyar Tambak village had the lowest access to latrine (93.54\%). Higher access to latrines was found in other villages such as Gunung Anyar village (97.94\%), Gunung Menanggal village (97.93\%), and Rungkut Tengah village (94.45\%) (Indonesian Ministry of Health, 2018).

Broadly speaking, in Gunung Anyar district, there were 17,684 permanent healthy lastrines, 18,062 families, 0 shared permanent healthy lastrines, and 378 open defecation cases (Indonesian Ministry of Health, 2018). Data on latrine access showed that RW 01 had the lowest use of latrines $(60.06 \%)$ when compared to RW 03 (100\%), RW 04 (100\%), RW 05 (100\%), RW 06 (100\%), RW 07 (100\%), RW 08 (100\%), and RW 09 (100\%) (Gunung Anyar Primary Healthcare Center, 2017). In Gunung Anyar Tambak village, RW 02 has been merged with RW 03 which is residential areas along with RW 09, while RW 01 is a village area. It means the Gunung Anyar subdistricts, especially in Gunung Anyar Tambak village, must pay more attention and efforts to increase latrine use and ownership. This study was conducted to analyze a relationship between respondent characteristics, knowledge, attitudes, and latrine ownership with the low use of latrines in RW 01 Gunung Anyar Tambak village, Gunung Anyar district, Surabaya city.

\section{METHODS}

This study was observational research using analytical methods and a cross-sectional research design. It was conducted by observing and distributing questionnaires to the subjects. Dependent and independent variables studied were observed at one time. The research was conducted in RW 01, Gunung Anyar Tambak village, Gunung Anyar district, Surabaya city. The research population was all families in RW 01 area which had access to latrines below $55 \%$ in 2017 , specifically RT 01 and RT 05 having 36\% access to latrines. The total population was 119 families, consisting of 50 families in RT 01 and 69 families in RT 05.

The research samples were people who owned a house in RW 01. Calculated by the Lameshow formula, the research sample size was 75 families as respondents. The respondents were family members aged at least 18 years and living in one house. They were chosen through probability sampling with the simple random sampling technique. A lottery was conducted to select families as respondents.

The dependent variable was the use of latrines, and the independent variables were respondent characteristics (education level and income level), knowledge, attitudes, and latrine ownership). Data were collected and obtained using guided interviews for gathering variables of knowledge, attitudes, latrine ownership, and respondent characteristics (education level and income level). Measurements for knowledge were stated in ten multiplechoice questions related to latrines use and ownership. It would be considered good if each respondent's score was greater than or equal to $75 \%$; adequate if $56 \%$ to $74 \%$; and poor if less or equal to $55 \%$. Attitude was measured from 10 statements, consisting of 5 positive statements and 5 negative statements, scored in the Likert scale. A score greater than or equal to 36.67 was considered good attitude; 23.34 to 36.66 adequate; and less than or equal to 23.33 poor. The data were then analyzed using a univariate analysis and then bivariate analysis with the Chi-square statistical test. If there were cells with an expected value of less than $5(20 \%)$, the fisher's exact test 
would be carried out with a $95 \%$ confidence level $(\alpha=0.05)$. This study passed the ethical clearance and received ethical approval from the Research Ethics Commission, Faculty of Dental Medicine, Universitas Airlangga with Certificate Number: 254/HRECC.FODM/V/2019.

\section{RESULTS}

This section explains the analyses of the dependent variable (latrine use) and independent variables (education level, income level, knowledge and attitude and latrine ownership).

Table 1. Distribution of Respondent Characteristics in RW 01, Gunung Anyar Tambak Village, Gunung Anyar District, Surabaya City in 2019

\begin{tabular}{lcc}
\hline \multicolumn{1}{c}{ Variables } & n & \% \\
\hline Education Level & & \\
\hline $\begin{array}{l}\text { Graduated from } \\
\text { elementary } \\
\text { school/equivalent }\end{array}$ & 9 & 12.00 \\
$\begin{array}{l}\text { Completed junior } \\
\text { high }\end{array}$ & 21 & 28.00 \\
$\begin{array}{l}\text { school/equivalent } \\
\text { Completed high } \\
\text { school/equivalent }\end{array}$ & 29 & 38.66 \\
$\begin{array}{l}\text { Diploma } \\
\text { Bachelors }\end{array}$ & 11 & 14.66 \\
Income Level & 5 & 6.68 \\
\hline High & 29 & 38.66 \\
Low & 46 & 61.34 \\
\hline
\end{tabular}

Regarding the respondent characteristics, most of the repsondents were high school graduates/equivalent, and the least were bachelors graduates. Most of the respondents also had income lower than the minimum wage of Surabaya (Table 1).

Knowledge and attitude variables among most of the respondents were categorized good in regards to the use of latrines (Table 2). The results on latrine ownership found that most of the respondents already had a (private) latrine
(Table 3). They mostly had good latrine use as well (Table 4).

Table 2. Distribution of Respondents' Knowledge and Attitudes in RW 01, Gunung Anyar Tambak Village, Gunung Anyar District, Surabaya City in 2019

\begin{tabular}{lrr}
\hline \multicolumn{1}{c}{ Variables } & n & \% \\
\hline Knowledge & & \\
\hline Good & 41 & 54.67 \\
Adequate & 22 & 29.33 \\
Poor & 12 & 16.00 \\
\hline Attitude & & \\
\hline Good & 46 & 61.33 \\
Adequate & 24 & 32.00 \\
Poor & 5 & 6.67 \\
\hline
\end{tabular}

Table 3. Distribution of Latrine Ownership in RW 01, Gunung Anyar Tambak Village, Gunung Anyar District, Surabaya City in 2019

\begin{tabular}{llc}
\hline \multicolumn{1}{c}{ Variable } & n & \% \\
\hline Latrine Ownership & & \\
\hline Own a Latrine (private) & 41 & 54.67 \\
Do not own a latrine & 34 & 45.33 \\
\hline
\end{tabular}

Table 4. Distribution of latrine use in RW 01, Gunung Anyar Tambak Village, Gunung Anyar District, Surabaya City in 2019

\begin{tabular}{lll}
\hline \multicolumn{1}{c}{ Variable } & n & $\%$ \\
\hline Latrine use & & \\
\hline Good & 44 & 58.66 \\
Poor & 31 & 41.34 \\
\hline
\end{tabular}

According to Table 5, the results of the bivariate test found that most of the respondents who had good use of latrines were graduates of senior high school/equivalent education level, while elementary school/equivalent education level had the smallest number of respondents with good use of latrines. Most of the respondents who had poor use of latrines were junior high school graduates/equivale few diploma/bachelors graduates had poor use of latrine. 
The results of the bivariate test with the Chi-square test showed that there was a significant relationship $(\mathrm{p}=0.000)$ between education level and latrine use. Moreover, it produced a contingency coefficient of 0.508 showing that the relationship between the variables was strong (Table 5).

The results of the bivariate test found that most of the respondents who had good use of latrines also had a high level of income. Most of the respondents who had inadequate use of latrines had a low level of income (Table 5).

The results of the chi-square test between described that there was a significant relationship $(\mathrm{p}=0.000)$ between the level of income and latrine use. Moreover, it produced a contingency coefficient of 0.444 proving that the relationship between the variables was strong enough. An OR-value of 8.882 showed that the respondents with a high level of income were 8.882 times more likely to have good latrine use compared to those with low income.

According to Table 6, the results of the bivariate test found that most of the respondents who had good use of latrines also had good knowledge. Meanwhile, most of the respondents who had poor use of latrines did not have sufficient knowledge.

Table 5. Relationship between Respondent Characteristics and Latrine Use in RW 01, Gunung Anyar Tambak Village, Gunung Anyar District, Surabaya City in 2019

\begin{tabular}{|c|c|c|c|c|c|c|c|c|}
\hline \multirow[t]{3}{*}{ Variables } & \multicolumn{4}{|c|}{ Latrine use } & \multirow{2}{*}{\multicolumn{2}{|c|}{ Total }} & \multirow{3}{*}{$\begin{array}{c}\text { P- } \\
\text { value }\end{array}$} & \\
\hline & \multicolumn{2}{|c|}{ Good } & \multicolumn{2}{|c|}{ Poor } & & & & \\
\hline & $\mathbf{n}$ & $\%$ & n & $\%$ & $\mathbf{n}$ & $\%$ & & \\
\hline \multicolumn{9}{|l|}{ Level of education } \\
\hline \multicolumn{2}{|c|}{$\begin{array}{l}\text { Graduated from elementary } \\
\text { school/equivalent }\end{array}$} & 2 & 22.2 & 7 & 78.8 & 9 & 100 & \multirow[t]{4}{*}{0.000} \\
\hline $\begin{array}{l}\text { Completed junior } \\
\text { school/equivalent }\end{array}$ & high & 5 & 23.8 & 16 & 76.2 & 21 & 100 & \\
\hline $\begin{array}{l}\text { Completed } \\
\text { school/equivalent }\end{array}$ & \multirow[t]{2}{*}{ high } & 23 & 79.3 & 6 & 20.7 & 29 & 100 & \\
\hline $\begin{array}{l}\text { Diploma } \\
\text { Bachelors }\end{array}$ & & 14 & 87.5 & 2 & 12.5 & 16 & 100 & \\
\hline \multicolumn{9}{|l|}{ Income Level } \\
\hline High & & 25 & 86.2 & 4 & 13.8 & 29 & 100 & \multirow[t]{2}{*}{0.000} \\
\hline Low & & 19 & 41.3 & 27 & 58.7 & 46 & 100 & \\
\hline
\end{tabular}

Table 6. Relationship between Knowledge and Attitudes towards Latrine Use in RW 01, Gunung Anyar Tambak Village, Gunung Anyar District, Surabaya City in 2019

\begin{tabular}{|c|c|c|c|c|c|c|c|}
\hline \multirow[t]{3}{*}{ Variables } & \multicolumn{4}{|c|}{ Latrine use } & \multirow{2}{*}{\multicolumn{2}{|c|}{ Total }} & \multirow[t]{3}{*}{ P-values } \\
\hline & \multicolumn{2}{|c|}{ Good } & \multicolumn{2}{|c|}{ Poor } & & & \\
\hline & $\mathbf{n}$ & $\%$ & $\mathbf{n}$ & $\%$ & n & $\%$ & \\
\hline \multicolumn{8}{|l|}{ Knowledge } \\
\hline Good & 30 & 73.2 & 11 & 26.8 & 41 & 100 & \multirow{3}{*}{0.006} \\
\hline Adequate & 7 & 31.8 & 15 & 68.2 & 22 & 100 & \\
\hline Poor & 7 & 58.3 & 5 & 41.7 & 12 & 100 & \\
\hline \multicolumn{8}{|l|}{ Attitude } \\
\hline Good & 34 & 73.9 & 12 & 26.1 & 46 & 100 & \multirow{3}{*}{0.003} \\
\hline Adequate & 8 & 33.3 & 16 & 66.7 & 24 & 100 & \\
\hline Poor & 2 & 40.0 & 3 & 60.0 & 5 & 100 & \\
\hline
\end{tabular}


Table 7. Relationship between Latrine Ownership and Latrine Use in RW 01, Gunung Anyar Tambak Village, Gunung Anyar District, Surabaya City in 2019

\begin{tabular}{|c|c|c|c|c|c|c|c|}
\hline \multirow{3}{*}{ Variables } & \multicolumn{4}{|c|}{ Latrine use } & \multirow{2}{*}{\multicolumn{2}{|c|}{ Total }} & \multirow[t]{3}{*}{ P-value } \\
\hline & \multicolumn{2}{|c|}{ Good } & \multicolumn{2}{|c|}{ Poor } & & & \\
\hline & $\mathbf{n}$ & $\%$ & $\mathbf{n}$ & $\%$ & $\mathbf{n}$ & $\%$ & \\
\hline \multicolumn{8}{|l|}{ Latrine Ownership } \\
\hline $\begin{array}{lll}\text { Own a } & \text { Latrine } \\
\text { (private) } & & \end{array}$ & 40 & 97.6 & 1 & 2.4 & 41 & 100 & 0.000 \\
\hline Do not own a latrine & 4 & 11.8 & 30 & 88.2 & 34 & 100 & \\
\hline
\end{tabular}

Based on the chi-square test results, there was a significant relationship $(\mathrm{p}=$ 0.006) between knowledge and latrine use. It obtained a contingency coefficient of 0.344 , meaning the relationship between knowledge and latrine use was fairly strong.

Table 6 presents the results of the bivariate test that most of the respondents who had good use of latrines also had good attitudes towards it. Most of the respondents who had insufficient use of latrines had adequate attitudes. The chisquare test results showed that there was a significant relationship $(p=0.003)$ between attitudes and latrine use. It resulted in a contingency coefficient of 0.364 , meaning that the relationship between knowledge and latrine use was classified strong enough.

Based on Table 7, the results of the bivariate test showed that most of the respondents who had good use also had (private) latrines; on the other hand, those who had poor use did not own latrines. The Chi-square test found a significant relationship $(\mathrm{p}=0.000)$ between latrine ownership and latrine use. A contingency coefficient value of 0.867 suggested that the relationship between latrine ownership and use was very strong, while an OR-value of 300.000 showed that the respondents who owned (private) latrines had 300.000 chances of having good latrine use when compared to those without latrines.

\section{DISCUSSION}

Gunung Anyar Tambak village has an area of $823.40 \mathrm{Ha}$, located in the Gunung
Anyar district. It is in the Eastern borders the Madura Strait, making it lush with large mangrove (47.90 Ha) and protected forests (479 Ha) as well as rivers and ponds (19.50 $\mathrm{Ha})$. It is near the North borders which is Medokan Ayu village, to the South which is Tambak Oso village, to the East which is the Madura Strait, and to the West the Gunung Anyar village. There were still many rivers and ponds in the area, facilitating locals to practice open defecation. Most of the villages (93.54\%) had access to latrines; however, 151 families within RW 01 ranked the lowest amongst others did not have latrines (Indonesian Ministry of Health, 2018) Improving the health status can be done by providing physical environment facilities, for example, latrines. The availability of latrines would promote a healthy and clean environment. A latrine that meets the predetermined requirements can prevent the spread of disease and environmental pollution (Taringan, 2008). The indiscriminate disposal of feces has great potential in spreading diseases. An object contaminated by human feces may cause diseases for other humans (Notoatmodjo, 2003).

The chi-square result showed education level was significantly related to latrine use. It is in line with research conducted by Kurniawati and Windraswara (2017) who found there was a relationship between education level and usage behavior. They observed the respondents with higher education were 3.6 times more likely to use latrines than respondents with low education. In the KATAJAGA 
program in Gunungpati district, Semarang, research conducted by Oktanasari et al.c (2017) supports the result by saying education level had a significant relationship with latrine use. Individuals with a higher education level tend to have broader insights, thereby making them embarrassed for practicing open defecation. While among people with a low education level would, open defecation is commonly considered as a culture. However, this study is not in line with research conducted by Horhoruw et al. (2014) who found education level was not related to latrine use.

The research results indicated that the majority of respondents with a high level of education (senior high school/equivalent, diploma, and bachelors) had good use of latrines. Meanwhile, the respondents with low education (elementary high school/equivalent and junior high school/equivalent) had poor use of latrines.

Further, the chi-square results found that there was a significant relationship between income level and latrine use. This study is in line with research of Sari (2016) that highlighted a significant relationship between income levels and family defecation in Kerjokidul village, Ngadirejo district, Wonogiri regency. People who generally have a high economic level can provide defecation facilities, affecting the use of latrines, while people with a low income level choose to defecate on a river or other open areas due to economic constraints.

This study is also in line with research of Nur (2015) which noted that there was a significant relationship between income levels and defecation behavior. She explained that people with low income did not feel the need to participate in latrine ownership. In turn, they less use latrines. It was also considered more comfortable to defecate on catfish ponds or other ponds because it was difficult to build a latrine. The respondents who had low income had
9.500 times greater chances of using latrines less frequently.

This study is not in line with research conducted by Apriyanti et al.c (2019) who demonstrated that family income did not have a relationwhip with latrine use $(\mathrm{p}=1.000)$. The respondents with high income sometimes did not have a proper waste disposal site. Those with high income even indicated that free latrines were only for low-income people. The results indicated that most of the respondents with high income also had good use of latrines. While, the majority of respondents with low income had less use of latrines.

Knowledge had a significant relationship with latrine use. The result is in line with research of Sayati (2018) knowledge was significantly related to the use of healthy latrines as observed in the work area of 23 Ilir Primary Healthcare Center Palembang in 2018 ( $\mathrm{p}=0.012)$. People with insufficient knowledge about latrine use would lack capacity of using the latrines. Limited knowledge results in a lack of health care efforts in the community. This study is also in line with research of Talinusa et al. (2017) between knowledge and defecation behavior in Jayakarsa village where there was a relationship $(\mathrm{p}=0.000)$. Research by Paramita (2016) supports this study by saying there was a significant relationship between knowledge and use of latrines ( $p=$ 0.018). Good use of latrines is supposed to be followed by good knowledge. The research also showed that the majority of respondents with good knowledge would have good use of latrines. The majority of respondents with sufficient or insufficient knowledge had poor use of latrines.

The Chi-square test obtained a significant relationship between attitudes and latrine use. This result is in line with that of Nasfryal et al (2019) in residential areas of Purus village, West Padang district. Attitudes and latrine use were equal; in another sense, the better the attitudes of eating, the better the use of latrines. 
Motivation may influence attitudes and be letting individuals involved in certain activities. Their involvement can stimulate participants to improve their awareness and eventually chance their attitudes.

The results are in line with other findings by Fatma and Putra (2018) who found the attitude and use of sanitary latrines had a significant relationship ( $\mathrm{p}=$ 0.034). Attitudes influenced one's behavior; in another sense, the relationship between attitudes and behavior was directly proportional. Attitude is related to one's actions to use latrines. It affects the choice of actions taken by individuals towards certain objects, personalities, and events (Otaya, 2012). The result also showed that most of the respondents with good attitudes also had good use of latrines. However, some respondents with adequate attitudes had poor use of latrines.

The Chi-square test also yielded that there was a significant relationship between latrine ownership and latrine use. This study is in line with research conducted by Caesar and Riza (2019) who found a relationship $(\mathrm{p}=0.026)$ between latrine ownership and latrine use in Setro Kalangan village, Kaliwungu district, Kudus regency. Research conducted by Pane (2008) supported the result as well (p $=0.000)$. Latrine ownership was closely related to its use $(\mathrm{OR}=27.04)$.

Similar research conducted by Husna and Mailanie (2018) also showed a relationship between latrine ownership and defecation habit $(p=0.029)$ in Semantok village, Sampoinet district, Aceh Jaya regency in 2017. The use of latrines depended on the community as the main spearhead in healthy latrine use according to health requirements. Defecation habit and latrine use are influenced by latrine ownership, but some people who own latrines still practice open defecation due to cultural influences. The results of this study also indicated that the majority of respondents who owned latrines also had good use of latrine. Meanwhile, those who did not own latrines had poor use of latrines.

\section{CONCLUSION}

The research results concluded that there was a significant relationship between respondent characteristics (education level and income level), knowledge, attitudes, and latrine ownership with latrine use in RW 01, Gunung Anyar Tambak village, Gunung Anyar district, Surabaya City. Latrine ownership was the strongest factor related to latrine use.

In order to increase the frequency of latrine use, it is necessary to improve attitudes, knowledge, and latrine ownership, specifically for people who still practice open defecation. There is a need to increase community support through community leaders, health care officers, and cadres to remind or urge to stop open defecation in the community.

\section{REFERENCES}

Apriyanti, L., Widjanarko, B. and Laksono, B. 2019. Faktor-faktor yang Mempengaruhi Pemanfaatan Jamban Keluarga di Kecamatan Jatibarang Kabupaten Brebes. Jurnal Universitas Diponegoro, 14(1), pp. 1-14. doi: 10.14710/jpki.14.1.1-14.

Caesar, D. L. and Riza, M. F. 2019. Hubungan Faktor Perilaku Keluarga dengan Kepemilikan Jamban di Desa Setro Kalangan, Kecamatan Kaliwungu, Kabupaten Kudus. Jurnal Kesehatan Masyarakat, 7(1), pp. 62-92.

Fatma, F. and Putra, V. J. A. 2018). Penggunaan Jamban Saniter di Jorong Uba Kenagarian Koto Tangah, Kecamatan Tilatang Kamang. Journal Human Care, 3(3), pp. 169-174. doi: http://dx.doi.org/10.32883/hcj.v3i3. 36.

Gunung Anyar Health Center r, 2017. 
Laporan Akses Jamban Puskesmas Gunung Anyar. Surabaya: Puskesmas Gunug Anyar.

Horhoruw, A. et al. 2014. Perilaku Kepala Keluarga dalam Menggunakan Jamban di Desa Tawiri Kecamatan Teluk Ambon Kota Ambon. Jurnal Universitas Diponegoro, 9(2). doi: 10.14710/jpki.9.2.226-237.

Husna and Mailanie, S. 2018. Analisis Pengetahuan dan Kepemilikan Jamban dengan Kebiasaan Buang Air Besar Sembarangan (BABS) (Studi Kasus di Desa Seumantok, Kecamatan Sampoinet, Kabupaten Aceh Jaya). Majalah Kesehatan Masyarakat Aceh (MaKMA), 1(2), pp. 9-17. doi: http://dx.doi.org/10.32672/makma. v1i2.813.

Kurniawati, L. D. and Windraswara, R. 2017. Faktor-Faktor yang Berpengaruh terhadap Perilaku Kepala Keluarga dalam Pemanfaatan Jamban di Pemukiman Kampung Nelayan Tambaklorok Semarang Abstrak. Public Health Perspective Journal, 2(1), pp. 7279.

Indonesian Ministry of Health, 2018. STBM (Sanitasi Total Berbasis Masyarakat). [Online]

Nasfryal, C., Nurhasan, S. and Fachruddin. 2019. Perilaku Penggunaan Jamban Keluarga pada Lingkungan Perumahan Penduduk Kota Padang. Jurnal UNISSULA, pp. 1-11.

Nur, W. N. 2015. Hubungan Karakteristik Pemilik Rumah dengan Perilaku Buang Air Besar Sembarangan (BABS) di Wilayah Kerja Puskesmas Sambungmacan II Kabupaten Sragen. Skripsi. Surakarta: Universitas Muhammadiyah Surakarta.

Notoatmodjo, 2003. Ilmu Kesehatan Masyarakat, Jakarta: Rineka Cipta.

Oktanasari, W., Laksono, B. and Indriyanti, D. R. 2017. Faktor Determinan dan Respon Masyarakat Terhadap
Pemanfaatan Jamban dalam Program Katajaga di Kecamatan Gunungpati Semarang. Public Health Perspective Journal, 2(3), pp. 279-286.

Otaya, L. G. 2012. Pengetahuan, Sikap dan Tindakan Masyarakat terhadap Penggunaan Jamban Keluarga. Jurnal Health and Sport, 5(2).

Pane, E. 2008. Pengaruh Perilaku Keluarga terhadap Pengguaan Jamban. National Public Health Journal, 17550(1), pp. 229-234. doi: http://dx.doi.org/10.21109/kesmas. v3i5.215.g215.

Paramita, R. D. 2016. Faktor Penyebab Rendahnya Penggunaan Jamban di RW 02 Desa Gempolklutuk, Kecamatan Tarik, Kabupaten Sidoarjo. Skripsi. Surabaya: Universitas Airlangga.

Sari, N. A. 2016. Hubungan Tingkat Pengetahuan, Sikap dan Tingkat Pendapataan dengan Perilaku Buang Air Besar Keluarga di Desa Kerjokidul Kecamatan Ngadirejo Kabupaten Wonogiri. Skripsi. Surakarta: Universitas Muhammadiyah Surakarta.

Sayati, D. 2018. Faktor-Faktor yang Mempengaruhi Pemanfaatan Jamban Sehat di Wilayah Kerja Puskesmas 23 Ilir Palembang Tahun 2018. Jurnal 'AISYIYAH MEDIKA, 2, pp. 57-68.

Talinusa, C. E. et al. 2017. Determinan Perilaku Buang Air Besar Sembarangan di Desa Jayakarsa, Kecamatan Likupang Barat, Kabupaten Minahasa Utara. Kesmas, 6, pp. 1-8.

Taringan, E. (2008) Faktor-Faktor Yang Mempengaruhi Partisipasi Keluarga dalam Penggunaan Jamban di Kota kabanjahe. Tesis. Medan: Universitas Sumatera Utara. 